平成 2 年レーザー学会学術講演会第10回年次大会

$25 \mathrm{p}$ II 8

$$
\text { レーザーと21世紀 }
$$

-明日は光の時代-

(財)レーザー技術総合研究所·近畿大学理工学総合研究所

山中 千代 衛

1.はじめに

レーザーは今世紀最大にして最後の発明と言われている。1960年に初めてレーザー発振が実現 して以来、早くも 4 分の 1 世紀がたち、永らく科学の華ともてはやされていたレーザーは、いよ いよ工業の果実として産業界に登場(1)して来た。

量子効果というものは、たいていミクロの世界にしか現れないのであるが、レーザー現象は マクロの世界に発現し、原子、分子の機能がそのまま集約されて、我々の五感にうったえるので ある。コヒーレントなレーザー光では、電波でできる技術はほとんどすべて光の領域に持ち込 まれることになる。光通信、画像処理、光化学、物質の加工、医療、同位体分離、その他も万も ろの計測に使われ、最近では核融合の開発にも重要な役割を担っている。レーザーには限りない 可能性が秘められているのである。

しかし、新技術が発明され一挙に産業界のアイドルになるかと言うとそうではない。1947年 トランジス夕が発明され、それがハイテクとして応用されたのは1961年のICの発明による。 10年以上たって世の中の実状にあったのである。レーザーはその発明以来、極めて高い科学的な 評価にもかかわらず 20 年間、摇籃期にあったといえよう。それが 1980 年代に入ってレーザー加 工、半導体レーザーの連続発振、光ファイバーの低損失化が相次いで実現した結果、今日の隆盛 の糹口が開かれたのである。

表1 和が国の科学技術活動の現状について

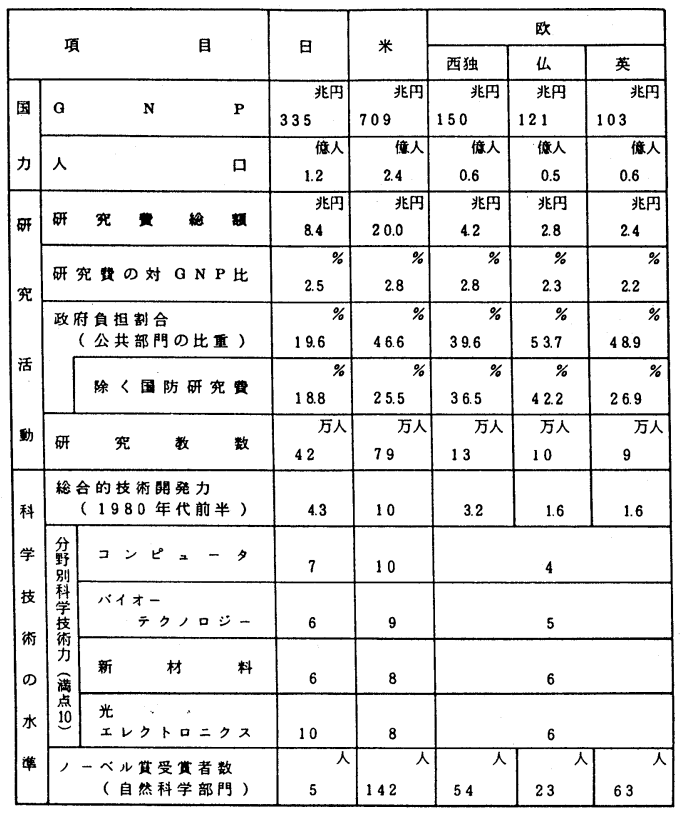


レーザーを中心とする光電産業は、1985年に1兆円、1990年は 2 兆円、10年後の 2000 年には 10兆円の大台を突破し国の主要産業の一つになるのではないかといわれている。ここではレー ザーという先端技術に焦点をあて、21世紀への展望(2)をのべることにしたい。表1は我が国の科 学技術の活動状況を示したもので、米国のさる経済誌によるこの国際的比較デー夕は甚だ興味深 いものがある。特にレーザーを中心とする光エレクトロニクスの評価の高いことに注目した w。

2. 極限技術とレーザー

レーザービームは自分の持つ波長程度の微小点にコヒーレントな光を集光することができる。 波長 $1 \mu \mathrm{m}$ 、出力 $1 \mathrm{TW}$ とすれば、焦点での電磁波の強さは $10^{20} \mathrm{~W} / \mathrm{cm}^{2}$ 、電界は $3 \times 10^{14} \mathrm{~V} / \mathrm{m}$ 、磁界は $10^{10} \mathrm{Oe}$ に達する。このような極度に高い電磁界を局所に集中印加できるため、従来の手段では実 現不可能であった現象が容易に発生する。

極限技術としてレーザーの出力はどこまで高められるか、そのクリティカルパスは何か。 レーザーのピーク出力を増大させるには図1のような条件がある。

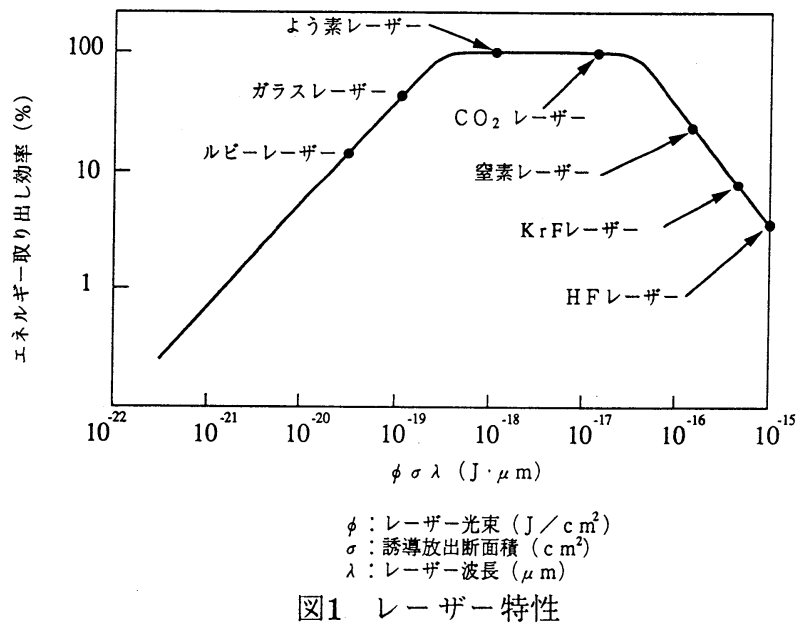

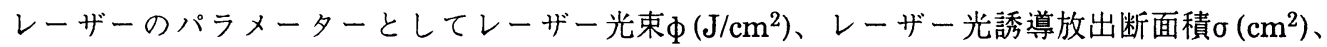
レーザー波長 $\lambda(\mu \mathrm{m})$ の積を横軸に、レーザーからのエネルギー取り出し効率 存のいろいろのレーザーの特性を明白に示すことができる。

比較的誘導放出断面積の小さいレーザーは内部に蓄積するエネルギーが大きくとれ、これを一 挙に放出すれば極めて高いピークパワーを発生する。そのためには誘導放出作用を強める必要が あり、より大きい光束 $\Phi$ を導入しなければならない。これは、レーザー媒質の損傷破壊を引き起 こす恐れがあるので、無制限に光束を高めることはできない。特に問題となるのはレーザー ビームの自己収束現象である。レーザービームの断面空間分布に異同があると、強い電界分布の 所は、電界で誘起される非線形屈折率のため光速が減少し、いわば凸レンズ状の性質を生じ、そ の部分の電界は屈折率の自己増倍と相まって急上昇し、破壊につながる。

一方誘導放出断面積の大きいレーザーでは、レーザー自身に大きなエネルギーを蓄積すること ができない。大出力を得ようとすれば、強力なエネルギー注入が必要であり、いわゆるパルス パワー技術に依存する。図1からわかるようにエネルギー取り出し効率(3)が最大になるのはよう 素レーザーや $\mathrm{CO}_{2}$ レーザーなどで、ガラスレーザーや窒素レーザーがそれについで高効率であ る。 


\section{3. 未来への展望}

レーザーは、極めて高いエネルギー集中投射することができるので、新しい技術(4) として、 レーザー 核融合(5)をはじめ、レーザー同位体分離(6)、レーザーリソグラフィー、レーザー加工 (7)、光誘起化学、レーザー医学応用(4)などがある。レーザーの先端技術に与えるインパクトとし て高く評価されている。図 2 に穴大要を例示してある。

\section{研究篗成园}

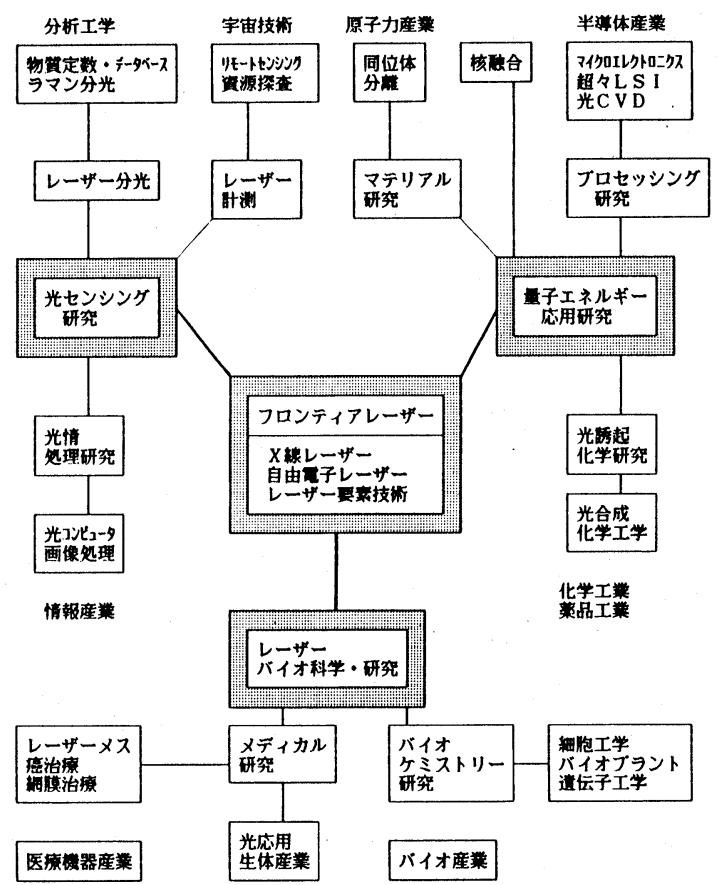

図2 レーザーの基本的特性に基づく主要な応用技術

\subsection{X線レーザー}

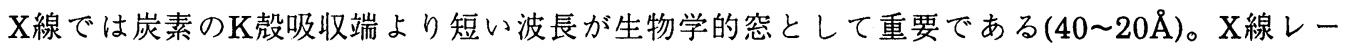
ザーのポンプパワーは、波長 $\lambda-3$ 則に従うから大出力が必要となり、核融合研究用レーザーがポ ンピングに用いられている。今後はレーザーパルス幅を短くしてピークパワーを上げることが 必要となる。200 600psパルスでは衝突励起方式が有効であり、10ps級のパルスでは内殸光電離 が可能となるため再結合方式が有効となる。さらにpsからサブpsパルスになると、ポンプパ ワーが強くなり、高密度高電離イオンを低温プラズマ中に発生することができる。この状態は再 結合方式X線レーザーに最適の条件である。阪大やLLNLで研究が進んでいる。

\section{2 電子·陽電子対生成}

レーザーにより真空を電離して電子.陽電子対を生成するにはポンデロモーティブポテンシャ ルのため、電子の静止質量エネルギーよりはるかに多くのエネルギーが必要で、波長 $1.06 \mu \mathrm{m} の$ レーザーでは $2 \times 10^{3} 0 \mathrm{~W} / \mathrm{cm}^{2}$ となる。したがって直接の対生成は困難である。しかし、レーザー 焦点に相対論的電子ビームを入射させるなら対生成は $1019 \mathrm{~W} / \mathrm{cm}^{2}$ で可能である。発生した陽電子

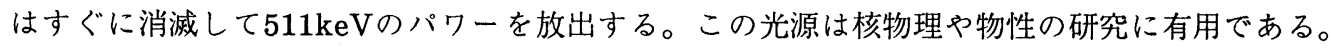


平成 2 年レーザー学会学術講演会第10回年次大会

3.3 レーザープラズマ加速器

シンクロトロン放射のため円形加速器では軽粒子を数 $\mathrm{TeV}$ 以上にすることは困難である。した がって現在は線形加速器に重点が置かれている。2マイルのStanford Linacは加速率 $17 \mathrm{MeV} / \mathrm{m}$ で ある。これ以上の加速率を得るにはレーザープラズマ加速器が有望である。波長の近い2レー ザー光のビートにより共鳴電子を加速する方法である。これで $30 \mathrm{GeV} / \mathrm{m}$ の加速率が期待されてい る。

\section{4 電子遷移核励起現象}

レーザーによる核物理の研究は核情報を原子準位の同位体シフトなどにより研究する程度であ る。これはレーザーの発生する電界がせいぜい $1014 \mathrm{~V} / \mathrm{m}$ のレベルで核内電界に比べると6桁も小 さいからである。しかし、レーザーにより内殸電子の振動を励起すると核の準位に影響を及ほす ことが実験でも確かめられている。この現象は、阪大でレーザーによる核励起現象として検出さ れ、235Uの新しい同位体分離の可能性を示すものとして注目されている。

\section{5 自由電子レーザー}

自由電子レーザー (FEL) は従来のレーザーと異なり、新しい原理に基づいたコヒーレント光源 である。このレーザーは、単純でかつ優れた利得媒質 (磁場中に電子ビーム中を入射)を用いるた め、波長可変、高出力、高効率を同時に達成できる可能性がある。

(1)共鳴条件(9)

FELは電子加速器、ウィグラーおよび光共振器の 3 つ要素から構成されている。ウィグラー に入射された電子ビームは図3に示すように、周期磁場中で蛇行運動して、放出光を発生する。光 パルスと電子ビームのパルスは、ほほ光速で伝播しウィグラー出口から放出され、偏向磁石で電 子パルスはシステムから取り出され、光パルスは光共振器中を往復する。発振のためには、繰り 返し入射される電子ビームと光共振器中を往復する光パルスがウィグラー中で重なって伝搬する よう正確に同期させることが必要である。

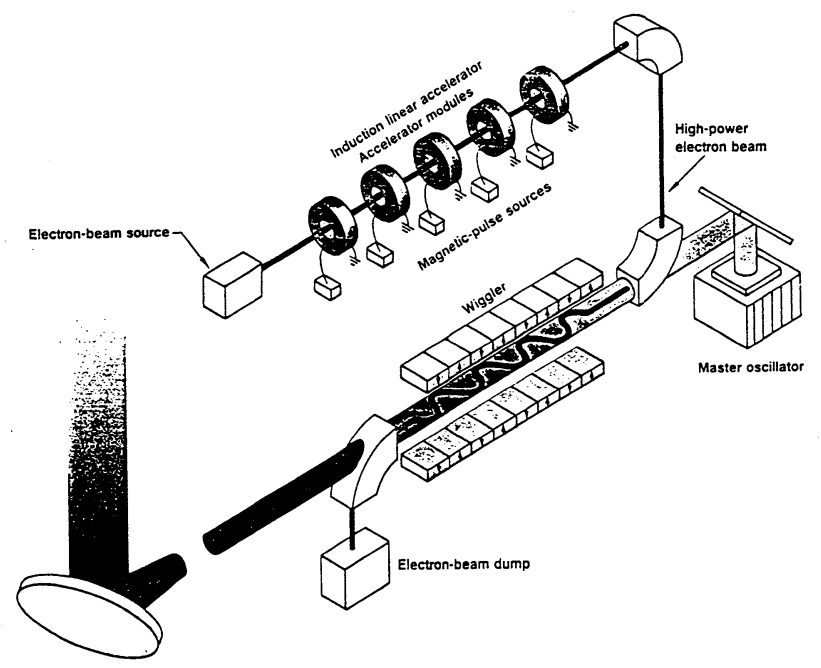

図3 自由電子レーザーにおける電子の運動

FELが増幅、発振を引き起こす共鳴的な相互作用は、電磁波の伝搬と電子の運動とがある整合状 態に入ることが必要である。この共鳴条件は、 
平成 2 年レーザー学会学術講演会第10回年次大会

$$
\Lambda_{s}=\frac{\Lambda_{w}}{2 \gamma^{2}}\left(1+\frac{K_{w}^{2}}{2}\right)
$$

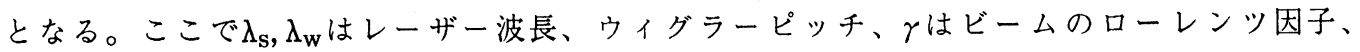
$\gamma^{2}=(1-\beta 2)-1, \beta=\mathrm{v} / \mathrm{c} 、 \mathrm{v}$ : 電子速度、C : 光速、 $\mathrm{K}_{\mathrm{w}}=2 \mathrm{neB}_{0} \lambda_{\mathrm{w}} / \mathrm{mc}^{2}$ である。ウィグラーの磁場強度

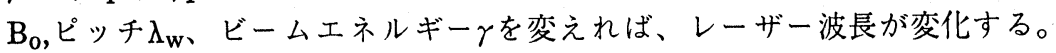

実際に自由電子レーザーの共鳴現象は逆ランダウ減衰と物理的に同じである。電子の平均速度 がこの共鳴速度を少し上回っているところで、自由電子レーザーは利得をもち、この共鳴速度を 少し下回っていると、電磁波長は吸収され電子は加速される。

\section{(2)誘導放射}

ウィグラー中で波長 $\lambda$ の電磁波と電子ビームが共鳴的に相互作用したとき、電子のエネルギー は変調を受ける。電子ビームはある距離伝播したのち、密度変調を生じる。今、波長 かに高いエネルギーの電子ビームを入射したとする。加速位相の電子はエネルギー変調により共 鳴条件からのずれが大きくなり、加速位相から減速位相への移動が起きる。一方、最初減速位相 にあった電子はエネルギー変調の結果、共鳴状態により近づき、長時間にわたり減速位相に滞在 する。以上の結果電子ビームは、ほぼレーザー光の周期で密度変調を受け、減速位相に集群化 (Bunching)する。すなわち、電子ビームは全体としてエネルギーを失い、そのエネルギーが誘 導放射としてレーザー光に変換されることになる。

電子ビームが充分集群化した状態では、個々の集群があたかも1つの荷電粒子であるかの様に 振舞って、いわゆるシンクロトロン放射が起きる。シンンクロトロン放射エネルギーは荷電qの 粒子ではq2に比例する。従って、ランダムに分布したN個の粒子が完全に群集化した場合には $(\mathrm{Nq})^{2}$ に比例する。すなわち、共鳴するレーザー光の入射により誘導された放射光強度は通常の シンクロトロン放射光のN倍になる。この誘導放射は、レーザー光の周期で配列した電子集群か らの放射となるため、レーザー光の位相に同調したコヒーレント光となる。

自由電子レーザー技術が確立された暁には、レーザープロセッシング、光誘起化学反応を利用 する光·電子デバイス製作及び新素材の開発、同位体分離、核融合等の原子力関連分野、及び外科 手術、生体医学への応用が期待される。

5.おわりに

1960年、テオドール・メイマン氏が初めてレーザー発振に成功した。その後、1970年代中頃ま でレーザーは技術育成の期間であった。1980年代に入って応用がレーザーを引っぱる時代に突入 し、ハイテクの先頭を走るレーザーは、光の世紀を築きつつある。この時、メイマン氏が日本賞 を授けられたことは、技術大国日本として誠に象徴的である。

X線レーザーをはじめ、自由電子レーザー(11)など極限レーザーを取上げ、その展望を与えた。 これら新型レーザーはそのポテンシャリティが高く、広く斯界の注目をあびている。

レーザーには広い産業応用が開拓されており、物質加工、バイオ医学応用、レーザー誘起化 学、センサ応用、計測などに大きな需要がある。また一方、研究指向分野では核融合 ${ }^{(12)}$ 、核物 理、粒子加速、光計算機、周波数標準など、枚挙に睱がない。

レーザーは21世紀ハイテク時代の中心的存在であって、米国はじめ先進諸国では国家的見地か ら高い優先度が与えられ、強力に研究開発が進められている。我が国においては今まで応用研究 が重視され、基礎研究はややもすると等閑にされ勝ちであったが、これからは基礎から応用へ一 貫した研究体制(13)を整えることが望まれている。 
平成 2 年レーザー学会学術講演会第10回年次大会

参考文献

(1) レーザー学会編: “レーザーハンドブック”オーム社 (1981), 山中千代衛: “レーザー光線”東海大出版 (1979)

（2）山中千代衛: “レーザーと末来社会”三田出版 (1985)

(3) 山中千代衛: “ハイテクの電気エネルギー技術への応用、大出カレーザー”、 電学誌 105, pp. 1066 - 1069 (1985)

(4) レーザー学会編: “レーザーハンドブック”オーム社 (1981)

(5) C. Yamanaka, et al.: "GEKKO XII Glass Laser System", IEEE J., QE-17 (1981)

（6）山中千代衛: “レーザー工学”、東海大出版、p.101, コロナ社 (June 1980)

（7）山中千代衛: “レーザー光線”、p.138(1979)

（8）山中千代衛: “レーザーと未来社会”三田出版、(1985)

(9) 三間图興ほか: “自由電子レーザー”、応用物理、57、pp 1468 - 1484 (1988)

（10）今崎一夫ほか: “自由電子レーザーと慣性核融合”、レーザー研究17、pp71-91 (1989)

(11) “自由電子レーザ開発調査研究報告書”、平成元年3月、関西産業活性化センター

（12）山中千代衛:“レーザー核融合研究の進歩”、信学会誌、71、pp. 697-718 (1988)

(13) C. Yamanaka:"Short Wave Length Lasers and their Application", Springer (1988) 